\title{
Characterization of Aquifer Parameters from Pumping Test Data in Part of Mubi Adamawa State - Nigeria
}

\author{
Lazarus G. Ndatuwong, Kasidi Simon
}

\begin{abstract}
Hydrogeological parameters in part of crystalline basement rock terrain were characterized using pumping test data. Five boreholes were used in this study for the evaluation of transmissivity ( $T$ ), hydraulic conductivity $(K)$ and specific capacity (Sc) of the study area. The transmissivity values obtained from the five boreholes shows that the aquifer potentiality of the study area varies from weak to high potential with an average value of $209.21 \mathrm{~m}^{2} / \mathrm{day}$, which signifies a moderate aquifer potential condition for the study area. The values of the hydraulic conductivity obtained shows that the aquifer is typical of clean sand (fine and coarse) and gravels. The result of the specific capacity obtained from the present study show that the aquifer in the study area is an unconfined aquifer.
\end{abstract}

Index Terms-Aquifer, Hydraulic conductivity, Pumping test, Specific capacity, Transmissivity.

\section{INTRODUCTION}

The evaluation of aquifer characteristics through the analysis of pumping test data has become a standard procedure in the evaluation of groundwater resource potential. Transmissivity and hydraulic conductivity are among the most important hydrogeological data needed for managing and evaluating of groundwater resources. Transmissivity describes the general ability of an aquifer to transmit water over the entire saturated thickness, while hydraulic conductivity measures this ability by unit area. The specific capacity of a well measures both the effectiveness of a well and also the aquifer characteristics of transmissivity and storativity. It is defined as the ratio of pumping rate and the drawdown [1]. The specific capacity is not a constant, but varies with pumping time, pumping rate, well construction, boundary conditions in the aquifer, and the influence of nearby pumping wells.

The evaluation of hydraulic properties of subsurface aquifers is an important task in groundwater resources assessment and development. This is because these properties are important in determining the natural flow of water through an aquifer and its response to fluid extraction [2]Besides, they are useful parameters for groundwater protection and prediction of contaminant transport [3]. Several techniques have been employed by hydrogeologist

Lazarus G Ndatuwong, Department of Pure and Applied Physics, Adamawa State University, Mubi, Nigeria

Kasidi Simon, Department of Geology, Adamawa State University, Mubi, Nigeria for the determination of the aquifer parameters. The most commonly used methods involve conducting pumping test on existing or newly drilled wells followed by analysis and interpretation of the pumping test data.

\section{LOCATION OF STUDY AREA AND GEOLOGY}

Mubi town and its environs lie within Latitudes $10^{\circ} 08^{1} \mathrm{~N}$ and $10^{\circ} 30^{1} \mathrm{~N}$ and longitudes $13^{\circ} 10^{1} \mathrm{E}$ and $13^{\circ} 25^{1} \mathrm{E}$. The town is located some $150 \mathrm{~km}$ Northeast of Yola and about $25 \mathrm{~km}$ from the Nigerian - Cameroun border (fig.1).

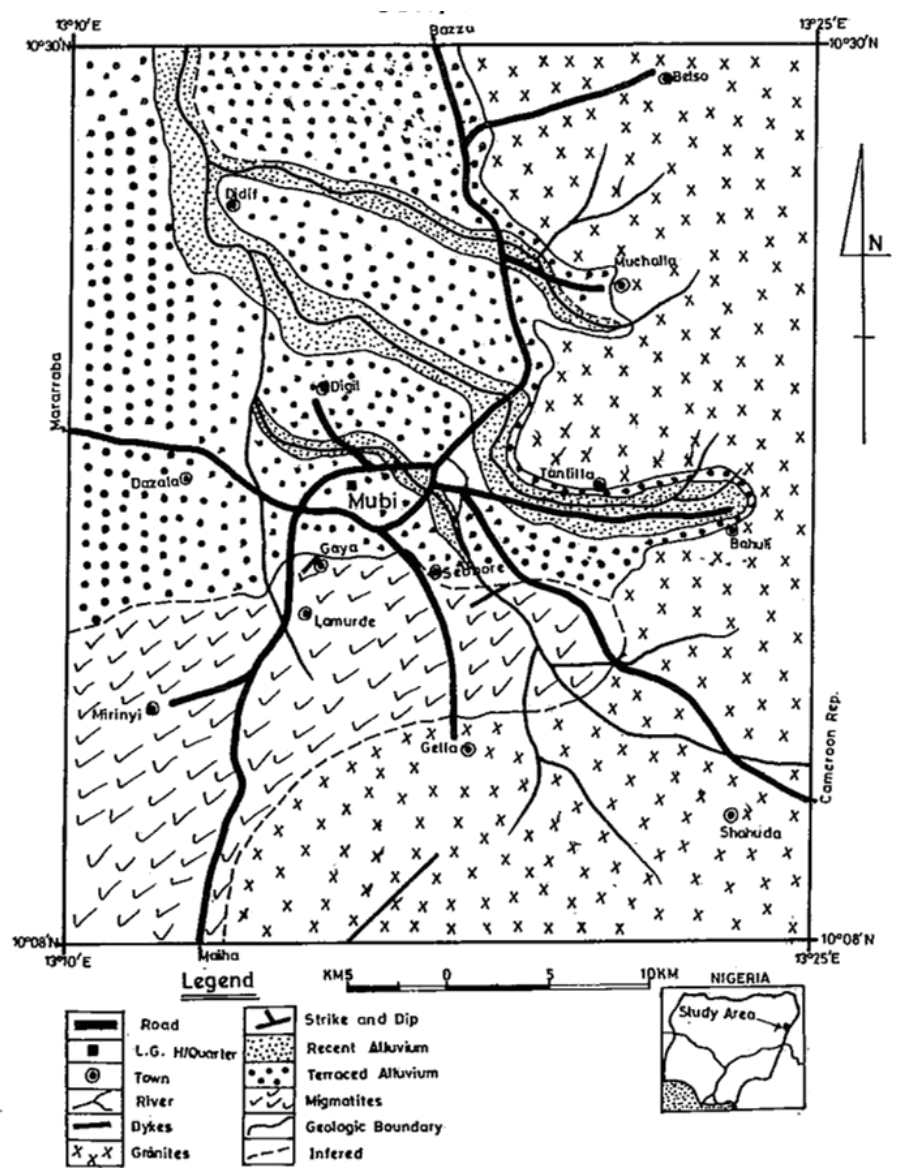

Fig. 1: The geologic map of Mubi and environs [4] 
The town is located within the Precambrian Basement Complex in the Northern part of Adamawa State. The rocks in the area are the Migmatite-gneisses and the Older granites. Some parts of the study area overlying the basement rocks are the alluvial deposits, which are derived from the weathering of the basement rock uphill and in situ. Geologic log data indicate that the thickness of the alluvial deposits to the bedrock range from about $5 \mathrm{~m}$ to $25 \mathrm{~m}$ along the river Yedsarem. The area is made up of two aquifer systems based on geological reconnaisance, the nature of the water and analyses of borehole lithologic logs. These are the fractured basement mainly magmatic[4].

\section{METHODOLOGY}

Constant rate test and recovery test measurement was conducted on five newly drilled boreholes in the study area. The drawdown measurement time of the boreholes varies from 50 to $210 \mathrm{~min}$. while the recovery time varies from 10 to $35 \mathrm{~min}$. Lithologic logs and supplementary geological and hydrogeological information were obtained from available maps of the study area and records of the boreholes. The logs enabled the establishment of the subsurface stratification, casing and screen positions, static water levels and aquifer textural properties. Water level measurement, drawdown, specific yield and the aquifer thickness was estimated from surface exposure and/or from the screen length of the aquifer. These data were used to determine aquifer hydraulic properties such as transmissivity (T), hydraulic conductivity (K) and specific capacity (Sc). The relevant data of the five boreholes properties from testing test results in terms of the static water level SWL, yield Q, final drawdown S, and thickness $\mathrm{h}$ of the aquifer are presented in Table 1.

Table 1: Boreholes data from pumping test

\begin{tabular}{clllllll}
\hline S/N & $\begin{array}{l}\text { Borehole } \\
\text { Location }\end{array}$ & $\begin{array}{l}\text { SWL } \\
(\mathrm{m})\end{array}$ & $\begin{array}{l}\mathrm{Q} \\
\left(\mathrm{m}^{3} / \mathrm{s}\right)\end{array}$ & $\begin{array}{l}\mathrm{S} \\
(\mathrm{m})\end{array}$ & $\begin{array}{l}\mathrm{H} \\
(\mathrm{m})\end{array}$ & $\begin{array}{l}\mathrm{RT} \\
(\mathrm{min})\end{array}$ & $\begin{array}{l}\text { S time } \\
(\mathrm{min})\end{array}$ \\
\hline 1 & Kolere & 3.70 & 0.008 & 0.02 & 12 & 10 & 90 \\
2 & Mubi & 3.82 & 0.0019 & 0.01 & 15 & 14 & 50 \\
& Central & & & & & & \\
3 & Lokuwa II & 1.91 & 0.009 & 0.37 & 17 & 35 & 210 \\
4 & Lokuwa I & 1.17 & 0.0130 & 0.21 & 29 & 35 & 210 \\
5 & ADSU 2 & 1.57 & 0.0015 & 0.11 & 23 & 35 & 90 \\
& & 7 & & & & \\
\hline
\end{tabular}

SWL: Static water level, Q: Pumping rate, S: Final drawdown, h: Aquifer thickness, RT: Recovery time

Pumping test data was analysed using Groundwater Pumping Test (GWPT) software by [5] to estimate the transmissivity and hydraulic conductivity of the aquifer based on the [6] non-equilibrium graphical method. This method has been found suitable where the abstraction well itself serves as the observation well, as is the case in the present study [7]. By this method, the transmissivity (T) is estimated by fitting a straight line to drawdowns on an arithmetic axis versus time on a logarithmic axis in a semi-log plot by;

$$
T=\frac{2.30 Q}{4 \pi \Delta S}
$$

Where $Q$ is pumping rate, $\Delta S$ is drawdown difference per $\log$ cycle.

While the hydraulic conductivity $K$, is calculated for each boreholes using,

$$
K=\frac{T}{h}
$$

Where $T$ is same as in (1) and $\mathrm{h}$ is the thickness of the aquifer (which is equivalent to the total screen length)

Specific discharge Sc, is also calculated by dividing pumping rate, $\mathrm{Q}$ over final drawdown, $\mathrm{S}$ given as;

$$
S c=\frac{Q}{S}
$$

\section{RESULTS}

The available lithologic logs shows that the water-bearing sections of the subsurface soil sequence comprises of the weathered/fractured basement which are of medium, fine and coarse-grained size granitic rock. The presence of fines in the aquifers reduces porosity and permeability and consequently the yield potential of the aquifers. The overburden of the basement areas are characteristically clayey and consolidated sand.

The drawdown verse time graph for the five boreholes as obtained from the GWPT software and the computed results for transmissivity and hydraulic conductivity are presented in fig. 2 .

\section{(a)}
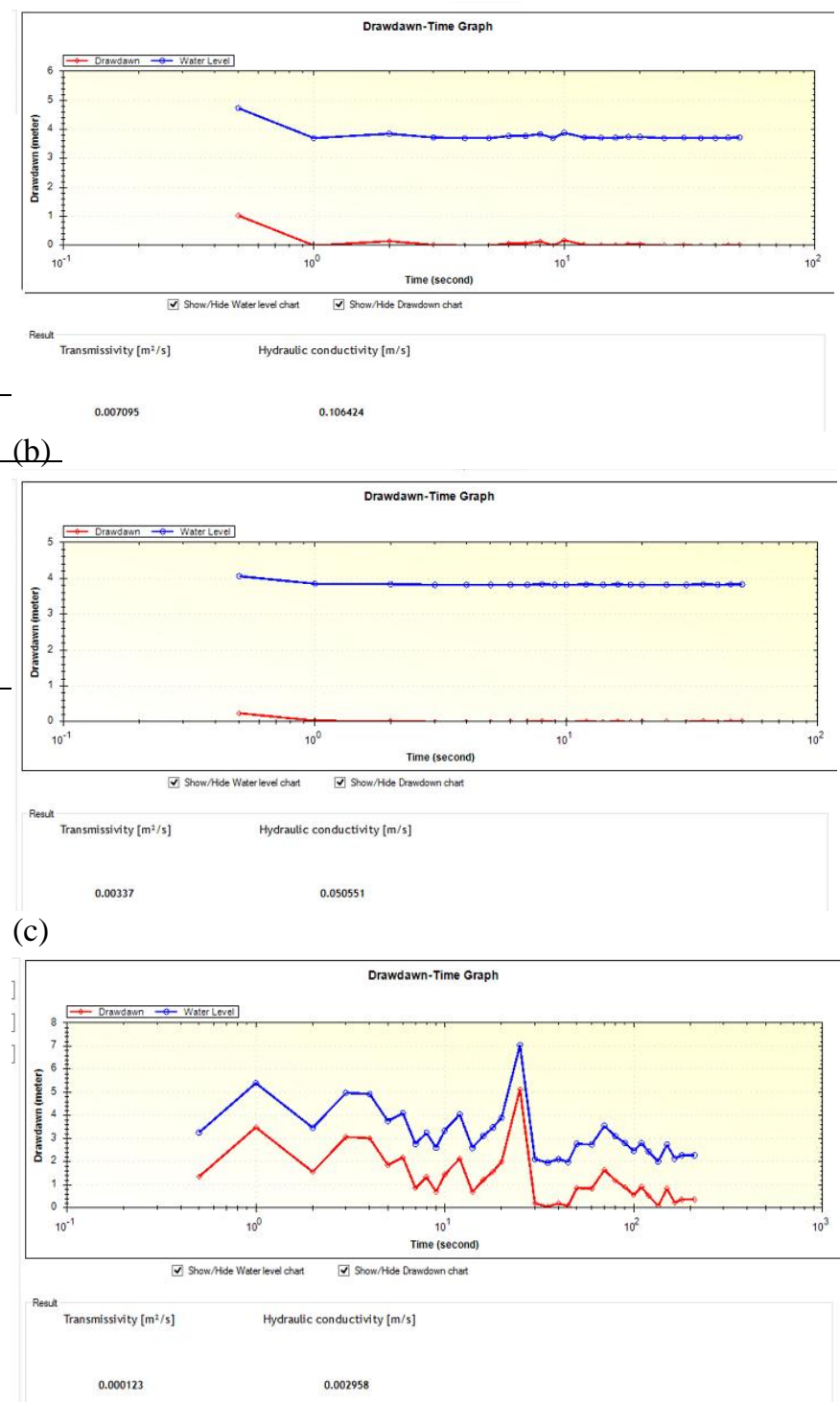
(d)
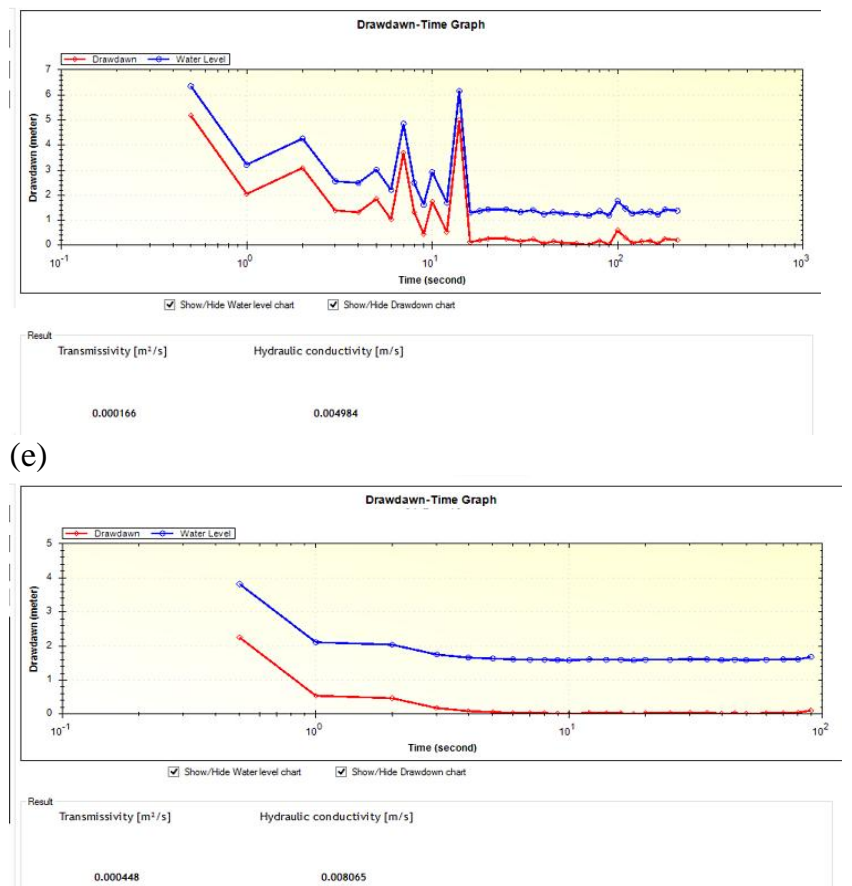

Fig. 2(a-e): Drawdown verse Time for the five testing wells

The result of the estimated transmissivity, hydraulic conductivity and storage coefficient for each of the boreholes was obtained using (1) - (3) and result presented in table 2.

Table 1: Estimated boreholes parameters the from pumping test

\begin{tabular}{llllll}
\hline $\mathrm{S} / \mathrm{N}$ & $\begin{array}{l}\text { Borehole } \\
\text { Location }\end{array}$ & $\begin{array}{l}\mathrm{T} \\
\left(\mathrm{m}^{2} / \mathrm{s}\right)\end{array}$ & $\begin{array}{l}\mathrm{K} \\
(\mathrm{m} / \mathrm{s})\end{array}$ & $\begin{array}{l}\mathrm{Sc} \\
\left(\mathrm{m}^{3} / \mathrm{s} / \mathrm{m}\right)\end{array}$ & [9] \\
\hline 1 & Kolere & $1.60 \times 10^{-1}$ & $2.40 \times 10^{-1}$ & 0.40 & \\
2 & Mubi Central & $3.37 \times 10^{-3}$ & $5.01 \times 10^{-2}$ & 0.19 & {$[11]$} \\
3 & Lokuwa II & $1.23 \times 10^{-4}$ & $2.96 \times 10^{-3}$ & 0.02 & \\
4 & Lokuwa I & $1.66 \times 10^{-4}$ & $4.98 \times 10^{-3}$ & 0.06 & \\
5 & ADSU 2 & $4.48 \times 10^{-4}$ & $8.07 \times 10^{-3}$ & 0.01 & \\
\hline
\end{tabular}

From the result in Table 2, transmissivity values range from $1.23 \times 10^{-4} \mathrm{~m}^{2} / \mathrm{sec}\left(10.62 \mathrm{~m}^{2} /\right.$ day) in Lokuwa area to $1.60 \mathrm{x}$ $10^{-1} \mathrm{~m}^{2} / \mathrm{sec}\left(691.20 \mathrm{~m}^{2} /\right.$ day) in Kolere with an average of 6.69 $\mathrm{x} 10^{-3} \mathrm{~m}^{2} / \mathrm{sec}\left(209.21 \mathrm{~m}^{2} /\right.$ day $)$ in the study area. According to transmissivity classification scheme of [8], the aquifer potentiality of the study area varies from weak to high potential within the study area. Borehole in Kolere area depicts a high aquifer potential condition while Lokuwa area has a low aquifer potential condition. The average value of $209.21 \mathrm{~m}^{2} /$ day signifies a moderate aquifer potential condition for the study area. These values are indication of the good permeability in the study area.

Hydraulic conductivity values is proportional to the transmissivity value in the study area. It ranges from $2.96 \mathrm{x}$ $10^{-3} \mathrm{~m} / \mathrm{sec}$ in Lokuwa area to $2.40 \times 10^{-1} \mathrm{~m} / \mathrm{sec}$ in Kolere with a mean value of $3.85 \times 10^{-6} \mathrm{~m} / \mathrm{sec}$. The values of the hydraulic conductivity obtained shows that the aquifer is typical of clean sand (fine and coarse) and gravels according to classification by[9] and [10]. This was observed from the core sample during drilling.

The specific capacity values range from $0.01 \mathrm{~m}^{3} / \mathrm{sec} / \mathrm{m}$ to $0.40 \mathrm{~m}^{3} / \mathrm{sec} / \mathrm{m}$. Reference [9] defined the storage coefficient
(S) as the volume of water that an aquifer releases or takes into storage per unit surface area of the aquifer per unit component of the head normal to that surface. In an unconfined aquifer, the storage coefficient corresponds to its specific yield and has a value that varies from 0.01 to 0.35 , while for confined aquifers, it varies from 0.00001 to 0.001 [11], [12]. The result obtained from the present study show that the aquifer of the study area is an unconfined aquifer.

\section{REFERENCES}

[1] W. K Summer,"Specific capacities of wells in crystalline rocks."Groundwater 10(6) 1972 pp37-47

[2] A. TBatayneh,"A hydrogeophysical model of the relationship between geoelectric and hydraulic parameters, Central Jordan."Journal of Water Resource and Protection, 1(1) 2009, pp 400-407.

[3] V,Shevnin, O. Delgado-Rodrı'guez, A. Mousatov, A. Ryjov,"Estimation of soil hydraulic conductivity on clay content, determined from resistivity data." Paper presented at the 19th symposium on the application of geophysics to engineering and environmental problems and constraints 2006, pp1464-1473

[4] G. IObiefuna, A. Nur, A.U Baba, and N.E Bassey, "Geological and geotechnical assessment of selected gully sites Yola Area Northeast, Nigeria."Environmental hydrology Journal Vol7 paper 6, 1999, pp.1-13.

[5] H. H Cooper, and C. E Jacob, "A generalized graphical method for evaluating formation constants and summarizing well-field history."Trans American. Geophysical Union 27, 1946, pp. 526-534

[6] A. C Tseand P. A Amadi, "Hydraulic properties from pumping tests data of aquifers in Azare area, North Eastern Nigeria." $J$. Appl. Sci. Environ. Manage. Vol. 12(4), 2008, pp 67 - 72

[7] S. Zenkai, "Practical and Applied Hydrogeology."Elsevier Inc. 2015, pp 43

[8] [9] D. K Todd, "Groundwater hydrology". John Wiley and Sons Singerpore, 1995.

$9]$ R. A Freeze and J. A Cherry, "Groundwater" Prentice-Hall, Englewood Cliffs, New Jersey USA. 1979, pp604.

10] [11] S. Ramakrishnan,"Groundwater." Chennai, 1998 pp 761

11] P. F. G Driscoll"Groundwater and wells." 2nd ed. Johnson Division, 1986, pp360. 